\title{
Penilaian Kinerja Sumber Daya Manusia Dalam Perspektif Audit Manajemen Dan Balance Scorecard
}

\author{
Benih Hartanti, Agus Susilo \\ Sekolah Tinggi Ilmu Ekonomi (STIE) PGRI Dewantara Jombang \\ *Korespondensi : benih@stiedewantara.ac.id
}

\begin{abstract}
Abstrak
Fenomena terkait dengan pengelolaan sumber daya manusia dalam organisasi, khususnya institusi pendidikan yang menjadi obyek dalam penelitian ini diharapkan dapat memberikan manfaat dan kontribusi dalam mendukung good corporate governance dan dapat meningkatkan kompetensi SDM sebagai asset terpenting dalam organisasi. Beberapa faktor dalam proses pengelolaan sumber daya manusia yang menjadi dasar penentu variable dalam penelitian ini antara lain adalah perencanaan tenaga kerja dan rekrutmen, fungsi orientasi dan penempatan dan fungsi pelatihan dan pengembangan. Penelitian yang dilakukan di STIE PGRI Dewantara Jombang ini berjenis kuantitatif dengan melibatkan 63 responden yang terdiri dari karyawan,dan dosen. Teknik analisa menggunakan Balance Score Card dan dilengkapi dengan analisa regresi linear berganda, F-Test dan T-Test. Hasil analisa menunjukkan bahwa kegiatan orientasi dan penempatan serta pelatihan dan pengembangan yang berpengaruh terhadap kinerja Dosen dan Karyawan. Sedangkan, posisi strategis STIE PGRI Dewantara terkait dengan pengelolaan karyawan berada pada titik yang menunjukkan bahwa, sttrategi paling tepat untuk dilaksanakan dalam jangka pendek.
\end{abstract}

Kata Kunci : Audit Sumber Daya Manusia, Kinerja Karyawan, Strategi.

\section{Abstract}

Phenomena related to the management of human resources in organizations, especially educational institutions that are the object of this research are expected to provide benefits and contributions in supporting good corporate governance and can improve the competence of HR as the most important asset in the organization. Several factors in the process of managing human resources that form the basis of variable determinants in this study include labor planning and recruitment, orientation and placement functions and training and development functions. The research conducted at STIE PGRI Dewantara Jombang was a quantitative type involving 63 respondents consisting of employees, and lecturers. Analysis techniques use Balance Score Card and are equipped with multiple linear regression analysis, F-Test and T-Test. The results of the analysis show that orientation and placement activities as well as training and development affect the performance of lecturers and employees. Whereas, the strategic position of STIE PGRI Dewantara related to the management of employees is at a point that shows that the most appropriate strategy is implemented in the short term.

Keywords: Human Resource Audit, Employee Performance, Strategy

\section{A. PENDAhUluAN}

Audit manajemen dirancang secara sistematis untuk mengaudit aktivitas, programprogram yang diselenggarakan, atau sebagian dari entitas yang bisa diaudit untuk menilai dan melaporkan apakah sumber daya dan dana telah digunakan secara efisien, serta apakah tujuan dari program dan aktivitas yang telah direncanakan dapat tercapai dan tidak melanggar ketentuan atau kebijakan yang telah ditetapkan oleh perusahaan (Bayangkara, 2008).

Manajemen sumber daya manusia merupakan penetapan pendekatan sumber daya manusia dengan dua tujuan yang ingin dicapai, yaitu tujuan untuk perusahaan dan tujuan untuk karyawan, dua kepentingan tujuan tersebut tidak dapat dipisahkan dan dilaksanakan dalam satu-kesatuan yang utuh. Sumberdaya manusia, sebagai salah satu asset perusahaan 
hendaknya dapat dikelola sebaik-baiknya melalui serangkaian proses yang terintegrasi sehingga tujuan bisa tercapai dan terukur.

Ada beberapa fenomena yang menarik terjadi pada dunia kerja saat ini, antara lain, fenomena pertama yaitu dengan semakin bertambahnya institusi pendidikan yang menyebabkan organisasi harus mampu mempertahankan tenaga kerjanya yang professional dan produktif agar dapat terjaga dari sisi kesejahteraan sehingga mampu memberikan loyalitas terhadap institusi. Fenomena kedua yaitu perhatian audit sumber daya manusia belum dilakukan secara komprehensif dengan pengukuran jelas atas keterkaitan dengan kinerja dan pencapaian tujuan organisasi, sedangkan sebagai asset terpenting perusahaan, sumber daya manusia haruslah dapat dikembangkan semaksimal mungkin.

Organisasi merupakan suatu sistem, tidak terkecuali organisasi nirlaba seperti institutusi pendidikan, yang didalamnya terdapat rangkaian dan hubungan antar bagian komponen yang bekerja sama secara keseluruhan. Dimana setiap komponen merupakan sub sistem yang memiliki kekayaan sistem bagi dirinya. Terdapat hubungan yang erat antara kinerja perseorangan dengan kinerja organisasi. Dengan kata lain bila kinerja karyawan baik maka kemungkinan besar kinerja organisasi juga baik. Oleh karena itu organisasi harus benarbenar memperhatikan faktor sumber daya manusia sebagai aset penting.

Audit sumber daya manusia merupakan salah satu bagian dari audit manajemen. Audit sumber daya manusia adalah penilaian dan analisis yang komprehensif terhadap programprogram SDM. Audit ini melaksanakan penilaian (evaluasi) terhadap berbagai aktivitas sumber daya manusia yang terjadi pada perusahaan dalam rangka memastikan apakah kegiatan tersebut sudah berjalan secara ekonomis, efisien dan efektif dalam mencapai tujuannya dan memberikan rekomendasi perbaikan atas berbagai kekurangan yang masih terjadi pada aktivitas SDM yang diaudit untuk meningkatkan kinerja dari program atau aktivitas tersebut (Ginting, 2012). Kegiatan audit SDM selayaknya dilaksanakan secara beriringan dengan pengukuran yang lebih detail baik sehingga hasil yang disaijkan dapat dijadikan acuan dalam menentukan tindak lanjut, strategi dan evaluasi selanjutnya. Beberapa alat yang dapat digunakan dalam tahap evaluasi antara lain adalah balance scorecard yang telah

Penelitian sebelumnya oleh (Maharani, 2014) menggunakan variabel seperti perencanaan tenaga kerja, rekrutmen, seleksi, orientasi dan penempatan, serta pelatihan dan pengembangan. Hasil dari penelitian ini menunjukkan bahwa beberapa variabel berpengaruh terhadap kinerja karyawan. Selain itu, beberapa penelitian seperti yang telah dilakukan oleh (Sartin, 2008), (Yullyanti, 2009),(Pembagio, 2013), (Akhtan, 2013) dan Munparidi (2012) yang mendapatkan hasil yang sama dengan beberapa perbedaan di tingkat pengaruhnya pada kinerja karyawan.

Atas dasar perbedaan dari berbagai hasil penelitian tersebut serta beberapa rujukan terbaru mengenai alat ukur kinerja SDM, maka peneliti tertarik untuk melaukan penelitian mengenai pengaruh Internal audit SDM dan pengukuran balance scorecard SDM terhadap kinerja karyawan.

\section{B. TINJAUAN PUSTAKA}

\section{Teori Audit Manajemen}

Beberapa pengertian Audit Manajemen telah didefinisikan oleh beberapa ahli seperti (Sukrisno, 2013) yang menyatakan bahwa manajemen audit adalah suatu pemriksaan 
terhadap kegiatan operasi suatu perusahaan, termasuk kebijakan akuntansi dan kebijakan operasional yang telah ditentukan oleh manajemen, untuk mengetahui apakah kegiatan operasional yang telah ditentukan manajemen, untuk mengetahui apakah kegiatan operasi tersebut sudah dilakukan secara efektif, efisien dan ekonomis. Pengertian lain juga diungkapkan oleh (Bayangkara, 2008) yang menyatakan bahwa manajemen audit adalah pengevaluasian terhadap efisiensi dan efektivitas operasi perusahaan. Secara umum audit manajemen merupakan investigasi dari suatu organisasi dalam semua aspek kegiatan manajemen dari yang paling tinggi sampai dengan bawah dan pembuatan laporan audit mengenai efektivitasnya atau dari segi profitabilitas dan efisiensi kegiatan bisnisnya.

\section{Ruang Lingkup Audit Manajemen}

Menurut (Bayangkara, 2008) ruang lingkup audit manajemen yaitu seluruh aspek kegiatan manajemen beruapa seluruh kegiatan atau hanya mencangkup bagian tertentu dari aktivitas yang dilakukan. Periode audit juga bervariasi, mulai jangka satu minggu, beberapa bulan, satu tahun, atau beberapa tahun, sesuai dengan harapan yang ingin dicapai.

Tujuan audit manajemen menurut (Sukrisno, 2013) adalah sebagai berikut: a) Untuk menilai kinerja (performance) dari manajemen dan berbagai fungsi dalam perusahaan; $b$ ) Untuk menilai apakah berbagai sumber daya (manusia, mesin, dana, harta lainnya) yang dimiliki perusahaan telah digunakan secara efisien dan ekonomis; c) Untuk menilai efektivitas perusahaan dalam mencapai tujuan (objektive) yang telah ditetapkan oleh top management; d) Untuk dapat memberikan rekomendasi kepada top management dalam memperbaiki kelemahan-kelemahan yang terdapat dalam penerapan struktur pengendalian internal sistem pengendalian manajemen dan prosedur operasional perusahaan dalam rangka meningkatkan efisiensi, ekonomisasi dan efektivitas dari kegiatan operasional perusahaan.

\section{Manajemen Sumber Daya Manusia (MSDM)}

Sumber daya manusia (SDM) atau human resource dalam konteks bisnis, adalah orang yang bekerja dalam suatu organisasi yang sering pula disebut karyawan atau employee. Manajemen SDM berkaitan dengan kebijakan (policy) dan praktek-praktek yang perlu dilaksanakan oleh manajer mengenai aspek-aspek SDM dari manajemen kerja (job management). Diperlukan waktu yang panjang untuk memahami MSDM, karena pada hakikatnya mempelajari disiplin ilmu ini, sama artinya kita harus mempelajari pula disiplin ilmu lain seperti ilmu manajemen, ilmu psikologi dan ilmu-ilmu perilaku. Cara sistematis mempelajari MSDM adalah dimulai dengan memahami definisinya dan kemudia konteksnya. Menurut (Hasibuan, 2014) MSDM adalah ilmu dan seni mengatur hubungan dan peranan tenaga kerja agar efektif dan efisien membantu terwujudnya tujuan perusahaan, karyawan dan masyarakat. MSDM berkaitan dengan cara pengelolaan sumber daya insan dalam organisasi dan lingkungan yang mempengaruhinya agar mampu memberikan kontribusi secara optimal bagi pencapaian tujuan organisasi.

\section{Peranan MSDM}

Menurut (Hasibuan, 2014), MSDM dalam mengatur dan menetapkan program kepegawaian yang mencakup masalah-masalah seperti penetapan jumlah, kualitas dan alokasi, program kesejahteraan, peramalan kebutuhan, kebijakan dan undang-undang terkait, pendidikan dan pelatihan serta mengatur pensiun, pemberhentian dan pesangon.

Peranan SDM diakui sangat menentukan bagi terwujudnya tujuan, tetapi untuk memimpin unsur manusia ini sangat sulit dan rumit. Tenaga kerja manusia selain mampu, cakap dan terampil, juga tidak kalah pentingnya kemauan dan kesungguhanmereka untuk 
bekerja efektif dan efisien. Kemampuan dan kecakapan kurang berarti jika tidak diikuti moral kerja dan kedisiplinan karyawan dalam mewujudkan tujuan.

Hasibuan (2014) Fungsi manajemen sumber daya manusia meliputi perencanaan, pengorganisasian, pengarahan, pengendalian, pengadaan, pengembangan, kompensasi, pengintegrasian, pemeliharaan, kedisiplinan dan pemberhentian.

\section{Tujuan, Manfaat dan Pelaksanaan Audit Manajamen Sumber Daya Manusia}

Menurut Siagian, 2015) Perusahaan yang telah meyelenggarakan audit mengetahui bahwa penyelenggara audit manajemen dapat berasal dari dalam organisasi, tetapi tidak mustahil berasal dari luar organisasi yang bersangkutan.Tujuan dilaksanakannya audit manajemen adalah untuk meneliti dan menilai kinerja perusahaan disoroti dari sudut pandang peningkatan efisiensi, efektivitas dan produktivitas kerja, baik dalam arti perusahaan sebagai keseluruhan maupun dalam arti berbagai komponennya.

Teori tentang audit manajemen sumber daya manusia dan menurut pengalaman praktisi menunjukkan bahwa terdapat paling sedikit sepuluh jenis manfaat yang dapat dipetik oleh suatu perusahaan apabila audit dalam bidang fungsional yang sangat strategic ini terselenggara dengan baik diantaranya adalah identifikasi kontribusi satuan kerja, mengelola citra satuan kerja, sosialisasi mengenai kejelasan tanggung jawab, penerapan kebijaksanaan, identifikasi masalah dalam audit, peningkatan efisiensi serta sistem informasi yang handal.

Pelaksanaan Audit MSDM menurut (Hamilton, 2008) harus mengevaluasi cara departemen sumber daya manusia mengatur sumber daya manusia yang dimiliki perusahaan dengan merencanakan program audit mulai dari tujuan strategis perusahaan, penelusuran catatan dan dokumen, perolehan umpan balik, memantau proses, perencanaan kompensasi, membuat kesimpulan, menyusun laporan, meminta tanggapan manajemen sampai memantau tindak lanjut. Selain itu, telah dinyatakan oleh (Siagian, 2015) bahwa sasaran audit harus mencakup (1) perencanaan tenaga kerja (2) penyelenggaraan fungsi rekrutmen, (3) penyelenggaraan fungsi seleksi, (4) penyelenggaraan fungsi seleksi, (5) penyelenggaraan fungsi orientasi dan penempatan serta (5) penyelenggaraan fungsi pelatihan dan pengembangan.

\section{Balance Scorecard Sumber Daya Manusia}

Dalam proses pengelolaan organisasi, diperlukan adanya suatu proses yang komprehensif yang dapat dilaksanakan dalam mencapai tujuan, dengan melibatkan beberapa proses penting seperti penentuan visi dan misi, penilaian faktor internal dan eksternal, menentukan sasaran jangka panjang, menentukan strategi, melaksanakan strategi serta mengukur dan mengevaluasi strategi (David, 2011). Pada tahap evaluasi, kinerja SDM menjadi salah satu sorotan utama dalam organisasi tanpa mengabaikan bahasan penting seperti penilaian efektifitas SDM yang dinilai dari pencapaian target dan perilaku terkait, namun juga melaksanakan penilaian efisiensi yang mengacu pada pengukuran nominal yang telah dikeluarkan dan dibutuhkan dalam mengelola SDM. Pada pertimbangan inilah, Balance Scorecard menjadi salah satu alat bermakna yang dapat memberikan gambaran konkrit kinerja SDM. Secara umum, balance scorecard dipakai dalam mengukur kinerja SDM menggunakan empat perspektif penilaian, antara lain adalah perspektif strategis, perspektif operasional, perspektif pelanggan dan perspektif keuangan (Walker, 2001). Pada empat perspektif tersebut, beberapa detail pengukuran dilakukan dengan mempertimbangkan beberapa kriteria detail dalam bentuk indikator kinerja pada table berikut. 
Tabel 1. Indikator Penilaian dalam Balance Scorecard Sumber Daya Manusia

\begin{tabular}{|c|c|}
\hline Indikator & Deskripsi \\
\hline \multicolumn{2}{|l|}{ Turnover Pegawai } \\
\hline Biaya/Rekrutmen & $\begin{array}{l}\text { Perhitungan biaya untuk rekrutmen, rujukan pegawai, relokasi, } \\
\text { perekrut, jumlah perekrutan }\end{array}$ \\
\hline Biaya Turnover & $\begin{array}{l}\text { Perhitungan biaya terminasi, perekrutan baru, lowongan kerja dan } \\
\text { kurva pembelajaran }\end{array}$ \\
\hline Tingkat Turnover & $\begin{array}{l}\text { Persentase tingkat perputaran adalah jumlah pemisahan dibagi dengan } \\
\text { jumlah rata-rata karyawan. Pemisahan termasuk karyawan yang } \\
\text { berhenti, diberhentikan, pindah ke perusahaan lain atau pensiun }\end{array}$ \\
\hline Waktu untuk mengisi posisi/jabatan & $\begin{array}{l}\text { Waktu yang diperlukan untuk mengisi kekosongan. Semakin lama } \\
\text { suatu posisi tetap kosong, semakin besar gangguan terhadap } \\
\text { produktivitas. }\end{array}$ \\
\hline \multicolumn{2}{|l|}{ Rekrutmen } \\
\hline Periode kekosongan posisi/jabatan & Jumlah hari keseluruhan posisi/jabatan kosong \\
\hline Penilaian kerja karyawan baru & $\begin{array}{l}\text { Penilaian kinerja rata-rata karyawan baru, dibandingkan dengan } \\
\text { periode sebelumnya }\end{array}$ \\
\hline $\begin{array}{l}\text { Tingkat Turnover dari Karyawan } \\
\text { Baru }\end{array}$ & Presentase total turnover atas perekrutan pegawai dalam setahun \\
\hline $\begin{array}{l}\text { Dampak Keuangan dari Perekrutan } \\
\text { Baru }\end{array}$ & $\begin{array}{l}\text { Faktor-faktor yang menentukan biaya perekrutan yang tidak } \\
\text { maksimal: Biaya pelatihan, biaya SDM, biaya wawancara }\end{array}$ \\
\hline
\end{tabular}

\section{Retensi}

Turnover yang dapat dihindari Alasan karyawan meninggalkan organisasi dan tindakan apa yang mungkin diambil untuk mencegahnya

\begin{tabular}{ll}
\hline Keragaman Penyebab Turnover & Dampak Turnover \\
\hline $\begin{array}{l}\text { Dampak Keuangan dari Turnover } \\
\text { Pegawai }\end{array}$ & Faktor-faktor yang menentukan biaya saat terjadi turnover \\
\hline $\begin{array}{l}\text { Pelatihan dan Pengembangan } \\
\text { Kesempatan pembelajaran dan } \\
\text { pengembangan }\end{array}$ & $\begin{array}{l}\text { Persentase karyawan yang puas dengan pembelajaran dan peluang } \\
\text { pertumbuhan di organisasi }\end{array}$ \\
\hline Kepuasan Kerja & $\begin{array}{l}\text { Lima faktor penentu kepuasan kerja : Kompensasi total; pekerjaan itu } \\
\text { sendiri; Peluang promosi; Hubungan dengan supervisor; Interaksi dan } \\
\text { hubungan kerja dengan rekan kerja }\end{array}$ \\
&
\end{tabular}

Sumber : (Antariksa, 2009)

Selanjutnya, untuk memberikan penilaian yang lebih detail, setiap indikator diberi bobot (1 sampai 5) dan presentase kinerja. Penilaian dilakukan oleh manajer dengan menggunakan bahan penilaian lain seperti dokumen dan laporan audit.

\section{Model Penelitian}

Adapun variable dalam audit manajemen sumber daya manusia meliputi : perencanaan tenaga kerja, penyelenggaraan fungsi rekrutmen, fungsi seleksi, fungsi orientasi dan penempatan serta fungsi pelatihan dan pengembangan.

Berdasarkan rumusan masalah dan kerangka konseptual, maka penulis merumuskan hipotesis dalam penulisan skripsi ini adalah sebagai berikut:

1. Diduga audit manajemen sumber daya manusia yang terdiri dari perencanaan tenaga kerja dan penyelenggaraan rekrutmen, penyelenggaraan fungsi orientasi dan 
penempatan, penyelenggaraan fungsi pelatihan dan pengembangan berpengaruh secara parsial dan simultan terhadap peningkatan kinerja karyawan STIE PGRI Dewantara

2. Diduga variable fungsi pelatihan dan pengembangan mempunyai pengaruh yang paling dominan terhadap peningkatan kinerja karyawan STIE PGRI Dewantara

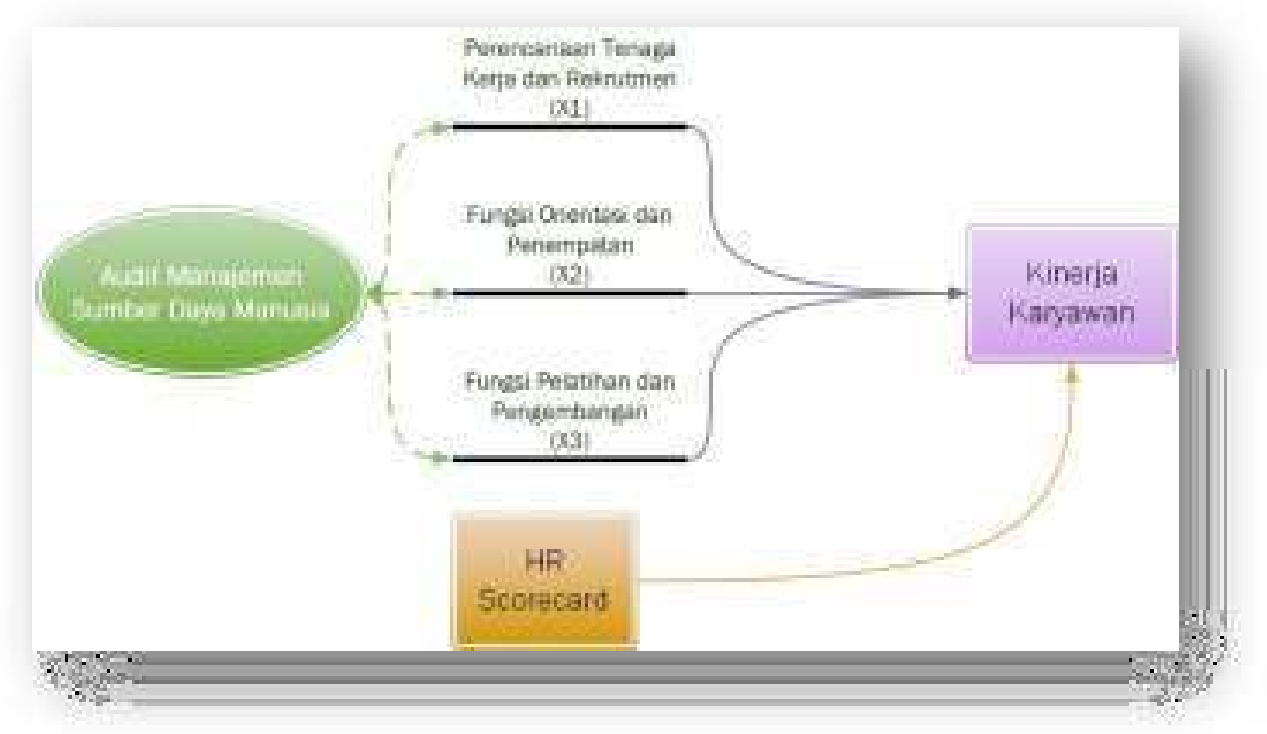

Gambar 1. Kerangka berfikir

\section{METODE PENELITIAN}

Desain penelitian yang digunakan dalam penelitian ini dengan menggunakan desain studi kasus yang dilakukan untuk menjawab permasalahan yang telah dirumuskan dalam perumusan masalah. Berdasarkan maksud dan tujuan penulis dalam memperoleh data dengan penelitian studi kasus yaitu menganalisa secara akurat, sistematis mengenai faktafakta yang ada dengan sifat tertentu yang bertujuan menjelaskan variable tentang suatu keadaan.

\section{Audit Manajemen Sumber Daya Manusia (Variabel X)}

Audit manajemen sumber daya manusia merupakan pemeriksaan terhadap kegiatan operasi suatu perusahaan termasuk kebijakan akuntansi dan kebijakan operasional yang telah ditentukan oleh manajemen, untuk mengetahui apakah kegiatan operasional yang telah ditentukan manajemen, untuk mengetahui apakah kegiatan operasi tersebut sudah dilakukan secara efektif, efisien dan ekonomis dengan indicator perencanaan tenaga kerja, penyelenggaraan fungsi rekrutmen, penyelenggaraan fungsi seleksi, penyelenggaraan fungsi orientasi dan penempatan serta penyelenggaraan fungsi pelatihan dan pengembangan.

\section{Kinerja Karyawan (Variabel Y)}

Manajemen kinerja karyawan adalah suatu pola tindakan yang dilaksanakan untuk mencapai tujuan perusahaan atau gambaran mengenai tingkat pencapaian pelaksanaan suatu kegiatan program kebijakan dalam mewujudkan sasaran, tujuan, visi dan misi organisasi yang tertuang dalam perumusan skema strategis (strategic planning) suatu 
organisasi. Indikator kinerja karyawan diukur berdasarkan index kepuasan mahasiswa terhadap kegiatan pelayanan oleh Dosen dan Tenaga Kependidikan.

Populasi dan sampel dalam penelitian ini adalah dosen dan karyawan mengambil STIE PGRI Dewantara. Responden yang terlibat dalam penelitian ini sebanyak 60 orang yang terdiri dari Dosen dan Tenaga Kependidikan.

Teknik pengamblian sampel dalam penelitian ini adalah metode Random yaitu teknik penentuan sampel diambil secara acak tanpa memperhatikan strata yang ada dalam populasi itu (Sugiyono, 2015). Skala pengukuran yang digunakan dalam penyusunan penelitian ini adalah Skala Likert.

\section{Balance Scorecard Sumber Daya Manusia (SDM)}

Penilaian kinerja dengan menggunakan Scorecard SDM dilakukan dengan memberikan bobot dengan kriteria sebegai berikut :

Tabel 2. Balance Scorecard

\begin{tabular}{|c|c|c|c|}
\hline Bobot & Keterangan & Presentase & Keterangan \\
\hline 1 & $\begin{array}{l}\text { Proses/cara kerja baik dan tidak } \\
\text { menimbulkan kesulitan dan } \\
\text { kerugian }\end{array}$ & $1 \%-20 \%$ & $\begin{array}{l}\text { Kesalahan/kegagalan yang terjadi hampir } \\
\text { selalu ada ( } 1 \text { dari } 3)\end{array}$ \\
\hline 2 & $\begin{array}{l}\text { Proses/cara kerja yang digunakan } \\
\text { dapat meminimalisasi kesulitan } \\
\text { dengan sedikit intervensi }\end{array}$ & $21 \%-40 \%$ & $\begin{array}{l}\text { Kesalahan/kegagalan yang terjadi dilakukan } \\
\text { berulang ( } 1 \text { dari } 20)\end{array}$ \\
\hline 3 & $\begin{array}{l}\text { Proses/cara kerja yang digunakan } \\
\text { menyebabkan sedikit kesulitan } \\
\text { dengan disertai dengan } \\
\text { penurunan performance }\end{array}$ & $41 \%-60 \%$ & $\begin{array}{l}\text { Kesalahan/kegagalan terjadi beberapa kali ( } 1 \\
\text { dari 80) }\end{array}$ \\
\hline 4 & $\begin{array}{l}\text { Proses/cara kerja menimbulkan } \\
\text { kesulitan dan kerugian }\end{array}$ & $61 \%-80 \%$ & $\begin{array}{l}\text { Kesalahan/kegagalan terjadi jarang terjadi (1 } \\
\text { dari 1000) }\end{array}$ \\
\hline 5 & $\begin{array}{l}\text { Proses/cara kerja menimbulkan } \\
\text { kesulitan dan kerugian yang } \\
\text { tinggi }\end{array}$ & $81 \%-100 \%$ & $\begin{array}{l}\text { Kesalahan/kegagalan hampir tidak pernah } \\
\text { terjadi ( } 1 \text { dari 100.000) }\end{array}$ \\
\hline \multicolumn{2}{|c|}{ Total Penilaian } & \multicolumn{2}{|c|}{ Total Penilaian setiap kategori $=$ Bobot $\mathrm{x} \%$} \\
\hline
\end{tabular}

\section{Jenis dan Sumber Data}

Adapun sumber data yang digunakan dalam penelitian ini yaitu berupa : a) Data Primer : Data primer adalah data yang diperoleh langsung dari STIE PGRI Dewantara yaitu dengan menggambarkan keadaan, struktur organisasi dan data lain yang berhubungan dengan obyek; b) Data Sekunder : Data sekunder yaitu data yang diperoleh bukan dari sumber asli atau pertama. Data ini bersumber dari dokumen yang diperoleh dari beberapa unit kerja baik dalam bentuk hardcopy maupun softcopy berhubungan dengan STIE PGRI Dewantara.

Selanjutnya, data yang masuk akan dianalisa menggunakan Analisis Regresi Linier Berganda, dengan persamaan: $\mathrm{Y}=\mathrm{a}+\mathrm{b} 1 \mathrm{x} 1+\mathrm{b} 2 \times 2+\mathrm{b} 3 \times 3$

(Sugiyono, 2015:275)

Keterangan: 
$\mathrm{X} 1=$ Perencanaan tenaga kerja dan rekrutmen

$\mathrm{X} 2$ = Penyelenggaraan fungsi orientasi dan penempatan

$\mathrm{X} 3$ = Penyelenggaraan fungsi pelatihan dan pengembangan

a $\quad$ Konstanta atau apabila harga $\mathrm{X}=0$

$\mathrm{b} \quad=$ Koefisien regresi masing-masing variable independent

Untuk mengetahui apakah terdapat pengaruh yang berarti diantara variable-variabel tersebut baik secara parsial maupun simultan juga dilakukan uji signifikan dengan $\mathrm{Uji} \mathrm{t}(\mathrm{t}$ test) yaitu untuk untuk mengetahui variable yang dominan mempengaruhi variable terikat secara parsial (masing-masing variabel) serta Uji $F$ ( $F$ test) untuk mengetahui pengaruh secara simultan (bersama-sama)

\section{E. HASIL PENELITIAN DAN PEMBAHASAN}

Pada penelitian ini, sebelum melakukan analisis data lebih lanjut, maka diperlukan untuk melakukan pengujian validitas dan pemeriksaan reliabilitas terhadap kuisioner sebagai tolak ukur penilaian. Berikut merupakan hasil uji validitas

Tabel 3. Hasil Uji Validitas

\begin{tabular}{lrc}
\hline \multicolumn{1}{c}{ Variabel } & $\begin{array}{r}\text { Kenyataan } r \\
r_{\text {tabel }}\end{array}$ & Keputusan \\
\hline Perencanaan tenaga kerja dan rekrutmen $\left(\mathrm{X}_{1}\right)$ & 0.7160 .250 & Valid \\
Penyelenggaraan fungsi orientasi dan penempatan $\left(\mathrm{X}_{2}\right)$ & 0.8640 .250 & Valid \\
Penyelenggaraan fungsi pelatihan dan pengembangan $\left(\mathrm{X}_{3}\right)$ & 0.8310 .250 & Valid \\
\hline
\end{tabular}

Berdasarkan hasil pengolahan data diatas menggunakan software SPSS dapat diketahui bahwa semua variabel dependen mempunyai nilai Pearson-Correlation ( $r$ ) yang lebih besar dari nilai $r_{0.05,51}$ yaitu sebesar 0.250. Sehingga dapat disimpulkan bahwa alat instrumen yang digunakan pada penelitian ini telah valid atau sudah mampu menjelaskan dan mengukur kerangka konsep kepuasan serta mewakili semua aspek yang dianggap sebagai kerangka.

Kemudian dilanjutkan dengan pemeriksaan reliabilitas yang akan diperiksa menggunakan nilai Cronbach's Alpha untuk mengukur apakah data dapat dipercaya. Berikur merupakan hasil pemeriksaan reliabilitas.

Tabel 4. Hasil Uji Reliabilitas

\begin{tabular}{lcc}
\hline \multicolumn{1}{c}{ Dimensi } & $\begin{array}{c}\text { Cronbach's } \\
\text { Alpha }\end{array}$ & Keputusan \\
\hline Perencanaan tenaga kerja dan rekrutmen $\left(\mathrm{X}_{1}\right)$ & 0.866 & Sangat Reliabel \\
Penyelenggaraan fungsi orientasi dan penempatan $\left(\mathrm{X}_{2}\right)$ & 0.855 & Sangat Reliabel \\
Penyelenggaraan fungsi pelatihan dan pengembangan $\left(\mathrm{X}_{3}\right)$ & 0.924 & Sangat Reliabel \\
\hline
\end{tabular}

Berdasarkan tabel diatas diketahui bahwa nilai Cronbach's Alpha pada semua variabel dependen berada pada kisaran 0.85-1.00 yang artinya data pada kelima variabel tersebut sudah reliabel atau dapat dipercaya untuk digunakan pada analisis berikutnya.

\section{Uji Asumsi IIDN (Identik, Independen, Distrbusi Normal)}

Pengujian asumsi residual IIDN digunakan untuk mengetahui secara perhitungan apakah data yang kita uji memenuhi ketiga asumsi yaitu identik, independen dan berdiistribusi normal sebelum membuat model. Berikut ini pengujian Asumsi residual Identik menggunakan uji Heterokedastisitas atau uji Glejser Hipotesis: 
$\mathrm{H}_{0}: \beta_{1}=0$ (tidak ada heterokedastisitas atau residual identik)

$\mathrm{H}_{1}: \beta_{1} \square 0$ (ada heterokedastisitas atau residual tidak identik)

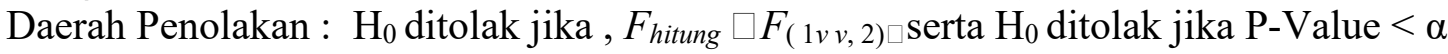

Berikut adalah hasil dari output software Minitab pengujian Glejser

Tabel 5 . Output Software Hasil Pengujian Glejser

\begin{tabular}{cllllll}
\hline Sumber Variasi & DF & SS & MS & F & P & \multirow{2}{*}{ F0,05(1,31) } \\
\hline Regresi & 5 & 0.45139 & 0.09028 & & & \\
Galat & 47 & 0.60053 & 0.01278 & 7.07 & 0.000 & 4,16 \\
Total & 52 & 1.05192 & & & & \\
\hline
\end{tabular}

Diketahui bahwa F Fitung sebesar 7.07 lebih besar dari $F_{\text {tabel }}$ sebesar 4,16 dan P-Value sebesar 0,00 lebih kecil dari $\alpha$ sebesar 0,05. Sehingga dapat diambil keputusan bahwa $\mathrm{H}_{0}$ ditolak dan dapat disimpulkan bahwa ada heterokedastisitas atau residual tidak identik. Jadi residual investasi luar negeri terhadap jumlah pengangguran dapat dikatakan tidak memenuhi asumsi residual identik.

Kemudian setelah residual telah memenuhi asumsi Identik, selanjutnya perlu diuji apakah residual telah memenuhi asumsi Indenpenden dengan menggunakan Uji Autokorelasi atau uji Durbin-Watson yang dapat dilihat sebagai berikut.

Hipotesis:

$\mathrm{H}_{0}: \mathrm{Q}=0$ (tidak ada autokorelasi atau independen antar residual)

$\mathrm{H}_{1}$ : $\mathrm{QP} 0$ (ada autokorelasi atau tidak independen antar residual)

Daerah Penolakan:

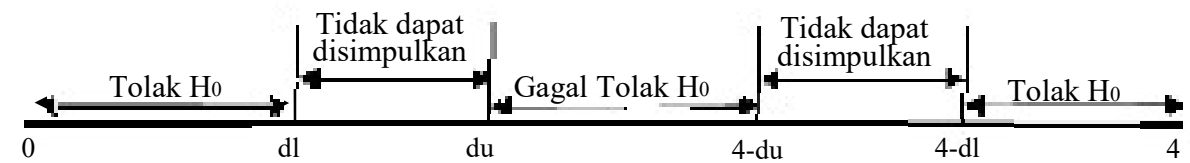

Nilai $\mathrm{d}_{\text {Lower }}$ adalah sebesar 1,01 dan nilai $\mathrm{d}_{\text {Upper }}$ adalah sebesar 1,65

Berdasarkan hasil Output Software Minitab menunjukkan bahwa nilai Durbin-Watson (d) sebesar 1,19477 yang artinya berada pada selang $\mathrm{d}_{\text {Upper }}<\mathrm{d}<4-\mathrm{d}_{U p p e r}$ sehingga keputusan yang diambil adalah gagal tolak $\mathrm{H}_{0}$, maka artinya data yang digunakan pada penlitian ini sudah memenuhi asumsi Independen.

Berikutnya dilanjutkan dengan uji distribusi Normal meggunkan uji Kolmogorov-Smirnov untuk mengetahui apakah residual sudah berdistribusi normal. Berikut merupakan hasil uji Kolmogorov-Smirnov

Hipotesis:

$\mathrm{H}_{0}$ : Residual berdistribusi normal

$\mathrm{H}_{1}$ : Residual tidak berdistribusi normal Daerah Penolakan :

$\mathrm{H}_{0}$ ditolak jika, $K S_{\text {hitung }} \square K S_{\text {tabel }}$ serta $\mathrm{H}_{0}$ ditolak jika $\mathrm{P}$-Value $<\alpha$

Statistik uji :

Berikut adalah hasil dari output software Minitab pengujian Kolmogorov-Smirnov yang ditunjukkan pada gambar dibawah ini 


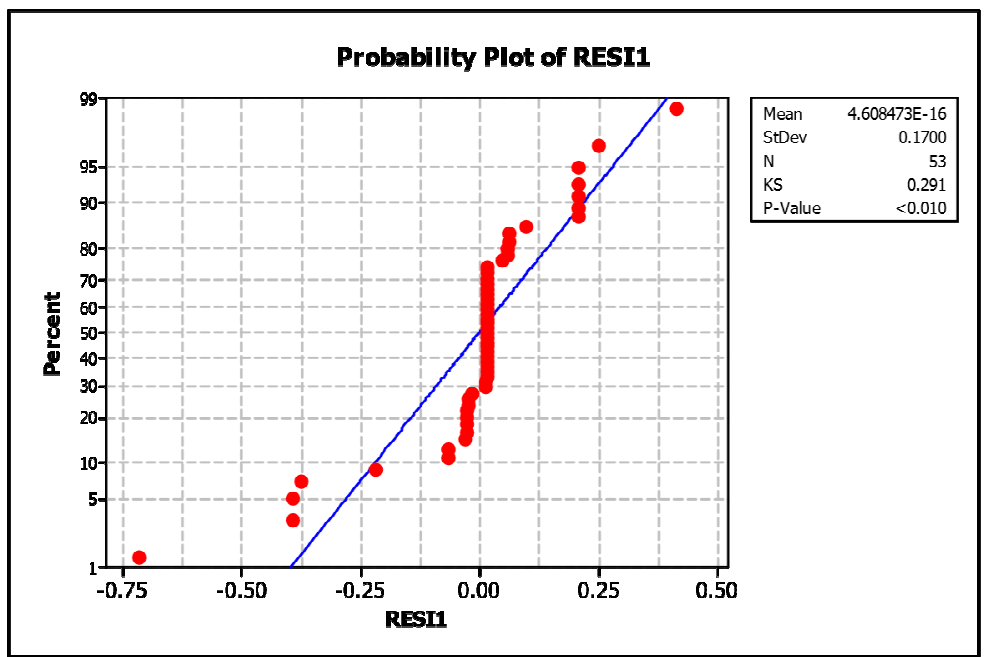

Gambar 2. Output Software Hasil Pengujian Kolmogorov-Smirnov

Gambar diatas menunjukkan bahwa nilai KS sebesar 0,291 lebih besar dari $\mathrm{KS}_{\text {tabel }}$ sebesar 0,231 dan P-Value sebesar 0,010 lebih kecil dari $\alpha$ sebesar 0,05. Sehingga dapat diambil keputusan bahwa gagal tolak $\mathrm{H}_{0}$ dan dapat disimpulkan bahwa residual berdistribusi normal.

\section{Uji Serentak dan Parsial (F-test and t-test)}

Pengujian Serentak dilakukan untuk melihat bagaimana pengaruh semua variabel prediktor secara bersama-sama terhadap variabel respon baik/signifikan atau tidak baik/non signifikan.. Berikut merupakan hasil uji serentak atau F-test pada data Kinerja Dosen dan Tenaga kerja Kependidikan.

Hipotesis

$\mathrm{H}_{0}: \square_{i} \mathrm{\square 0}$ (Tidak ada pengaruh secara signifikan antara variabel prediktor terhadap Kinerja

Dosen atau Tenaga kerja Kependidikan)

$\mathrm{H}_{1}: \square_{i} \square^{0}$ (Minimal ada 1 variabel prediktor yang berpengaruh terhadap Kinerja Dosen atau Tenaga kerja Kependidikan)

Daerah Penolakan : Tolak $\mathrm{H}_{0}$ jika $F \square F_{\square(1 v v, 2)}$ dengan $\mathrm{Qu} 0,05$

Pengujian serentak Variabel Respon dan 5 variabel prediktor menggunakan software minitab adalah sebagai berikut

\begin{tabular}{llcccc}
\multicolumn{7}{c}{ Tabel 6. F-test } \\
\hline Sumber & DF & SS & MS & F & P \\
\hline Regresi & 5 & 5.0256 & 1.0051 & & \\
Galat & 47 & 1.5027 & 0.0320 & 31.44 & 0,000 \\
Total & 52 & 6.5283 & & & \\
\hline
\end{tabular}

Tabel 4 menunjukkan nilai $F$ sebesar 31,44 yang berarti nilai $F_{\text {hitung }}$ lebih besar dibanding nilai $F_{\square(1 v v, 2)}$ atau 4,84. Sehingga keputusan yang diambil adalah tolak $\mathrm{H}_{0}$. jadi terdapat pengaruh secara signifikan antara Perencanaan tenaga kerja $\left(\mathrm{X}_{1}\right)$, Penyelenggaraan fungsi rekrutmen $\left(\mathrm{X}_{2}\right)$, Penyelenggaraan fungsi seleksi $\left(\mathrm{X}_{3}\right)$, Penyelenggaraan fungsi orientasi dan penempatan $\left(\mathrm{X}_{4}\right)$, Penyelenggaraan fungsi pelatihan dan pengembangan $\left(\mathrm{X}_{5}\right)$ terhadap Kinerja Dosen atau Tenaga kerja Kependidikan (Y). Kemudian selanjutnya dilakukan uji 
parsial atau $t$-test untuk menguji bagaimana pengaruh masing-masing variabel bebasnya secara sendiri-sendiri terhadap variabel terikatnya. Berikut merupakan hasil uji parsial atau t-test pada data Kinerja Dosen atau Tenaga kerja Kependidikan.

Hipotesis :

$\mathrm{H}_{0}: \mathrm{Q}_{i} \mathrm{C0}$ (Tidak ada pengaruh secara signifikan antara variabel prediktor (Xi) Kinerja Dosen atau Tenaga kerja Kependidikan)

$\mathrm{H}_{1}: \mathrm{I}_{i} \mathrm{Q}^{0}$ (Ada pengaruh secara signifikan antara variabel prediktor (Xi) Kinerja Dosen atau Tenaga kerja Kependidikan)

Daerah Kritis $\quad$ : Tolak $\mathrm{H}_{0}$ jika $T \square t_{\square / 2(n \square 1)}$ dan Pvalue $<\square$ dengant $t_{\square / 2(n \square 1)} \square$ 2,045

Pengujian serentak Variabel Respon dan 5 variabel prediktor menggunakan software minitab adalah sebagai berikut,

Tabel 7. t-test

\begin{tabular}{lccccc}
\hline \multicolumn{1}{c}{ Sumber } & Koefisien & SS & T & P & Keputusan \\
\hline Perencanaan tenaga kerja dan rekrutmen (X1) & & & & & \\
& & 0.03343 & 0.07230 & 0.460 .646 & Gagal Tolak $\mathrm{H}_{0}$ \\
& & & & & \\
$\begin{array}{l}\text { Penyelenggaraan fungsi orientasi dan } \\
\text { penempatan (X2) }\end{array}$ & & 0.3525 & 0.1036 & 3.400 .001 & Tolak $\mathrm{H}_{0}$ \\
$\begin{array}{l}\text { Penyelenggaraan fungsi pelatihan dan } \\
\text { pengembangan (X3) }\end{array}$ & & & & \\
\hline
\end{tabular}

Tabel diatas menunjukkan bahwa dari lima variabel prediktor hanya dua variabel yang berpengaruh secara individu terhadap Kinerja Dosen atau Tenaga kerja Kependidikan yaitu Penyelenggaraan fungsi orientasi dan penempatan $\left(\mathrm{X}_{2}\right)$ dan Penyelenggaraan fungsi pelatihan dan pengembangan $\left(\mathrm{X}_{3}\right)$ sedangkan tiga variabel prediktor lainnya tidak berpengaruh signifikan terhadap variabel respon.

\section{Model Regresi Linear Berganda}

Dari hasil test statistik didapatkan bahwa model Regresi Linier berganda terbaik untuk mengetahui faktor-faktor yang mempengaruhi Kinerja Dosen dan Tenaga kerja Kependidikan (Y) adalah sebagai berikut.

Tabel 8. Permodelan Regresi Linear Berganda

\begin{tabular}{cc}
\hline Persamaan Umum & Nilai $\boldsymbol{R}-\boldsymbol{S} \boldsymbol{q}$ \\
\hline $\mathrm{Y}=0.560+0.0334 \mathrm{X}_{1}+0.353 \mathrm{X}_{2}+0.375 \mathrm{X}_{3}$ & $77.0 \%$ \\
\hline
\end{tabular}

Berdasarkan model regresi linier berganda terbaik diatas didapatkan penjelasan bahwa:

1. Setiap tingkat Perencanaan tenaga kerja dan fungsi rekrutmen $\left(X_{1}\right)$ naik sebesar satu satuan, maka Kinerja Dosen dan Tenaga kerja Kependidikan (Y) akan naik sebesar $3.34 \%$ secara rata-rata dengan menganggap variabel lain adalah konstan

2. Apabila banyaknya Penyelenggaraan fungsi orientasi dan penempatan $\left(\mathrm{X}_{2}\right)$ naik sebesar satu satuan. maka Kinerja Dosen dan Tenaga kerja Kependidikan (Y) akan naik sebesar $35.3 \%$ secara rata-rata dengan menganggap variabel lain adalah konstan

3. Setiap banyaknya Penyelenggaraan fungsi pelatihan dan pengembangan $\left(\mathrm{X}_{3}\right)$ naik sebesar satu satuan. maka Kinerja Dosen dan Tenaga kerja Kependidikan (Y) akan naik sebesar $37.5 \%$ secara rata-rata dengan menganggap variabel lain adalah konstan 
4. Variabelitas Kinerja Dosen dan Tenaga kerja Kependidikan yang dapat dijelaskan oleh lima variabel prediktor adalah sebesar 77.0\% sedangkan sebesar 23.0\% dijelaskan oleh variabel lain di luar model. Semakin besar nilai kebaikan model maka semakin bagus modelnya.

\section{Penilaikan Kinerja dengan Balance Scorecard SDM}

Penilaian bobot dan presentase didasarkan pada data olahan dengan melaksanakan interview dengan pimpinan dan unit terkait. Selain itu, analisa laporan internal audit serta evaluasi anggaran juga dilakukan untuk menentukan presentase kinerja. Berikut merupakan hasil dari total penilaian kinerja.

Tabel. 9 Penilaikan Kinerja dengan Balance Scorecard

\begin{tabular}{|c|c|c|}
\hline KPI & Bobot (1 - 5) & Performance (\%) \\
\hline \multicolumn{2}{|c|}{$\mathbf{3}$} \\
\hline Biaya/Rekrutmen & 2 & $80 \%$ \\
\hline Biaya Turnover & 1 & $80 \%$ \\
\hline Tingkat Turnover & 1 & $70 \%$ \\
\hline Waktu untuk mengisi posisi/jabatan & 1 & $60 \%$ \\
\hline \multicolumn{2}{|c|}{} & \\
\hline Periode kekosongan posisi/jabatan & 1 & $80 \%$ \\
\hline Penilaian kerja karyawan baru & 3 & $70 \%$ \\
\hline Tingkat Turnover dari Karyawan Baru & 2 & $90 \%$ \\
\hline Dampak Keuangan dari Perekrutan Baru & 1 & $60 \%$ \\
\hline \multicolumn{2}{|c|}{3} & $85 \%$ \\
\hline Turnover yang dapat dihindari & 1 & $80 \%$ \\
\hline Keragaman Penyebab Turnover & 1 & $85 \%$ \\
\hline Dampak Keuangan dari Turnover Pegawai & 3 & 2 \\
\hline
\end{tabular}

\section{E. PENUTUP}

Berdasarkan pembahasan hasil yang dijelaskan sebelumnya, dapat disimpulkan bahwa peranan audit sumber daya manusia yang paling berpengaruh pada kinerja SDM adalah program dan perencanaan kegiatan yang fokus pada orientasi dan penempatan serta penyelenggaraan fungsi pelatihan dan pengembangan. Tentu saja, perencanaan, pelaksanaan serta pemantauan tindak lanjut tidak akan bisa lepas dari peran sistem informasi yang handal sesuai dengan yang diungkapkan oleh (Siagian, 2015), oleh karena itu dua kegiatan yang didasarkan pada hasil audit manajemen sumber daya ini selanjutnya dapat ditindaklanjuti sebagai fokus perencanaan kegiatan institusi dimulai dari dokumentasi mengenai jumlah kegiatan serta jumlah anggaran yang telah dikeluarkan, dibandingkan dengan total kegiatan pengelolaan MSDM untuk selanjutnya bisa dibuat 
perencanaan detail mengenai periode pelaksanaan serta periode anggaran. Selanjutnya, demi meningkatkan kompetensi SDM pada STIE PGRI Dewantara agar lebih memiliki kompetensi dan daya saing, maka indikator penilaian kompetensi bisa dirumuskan lebih detail dan disesuaikan dengan standar DIKTI serta standar mutu yang telah ditetapkan oleh Komisi Penjaminan Mutu STIE PGRI Dewantara. Namun, variable lain yang tidak berpengaruh seperti perencanaan kerja, fungsi seleksi dan rekrutmen tetap dijadikan temuan serta tindak lanjut dari audit manajemen MSDM agar selanjutnya fungsi audit manajemen SDM dapat berjalan secara komprehensif sehingga pengukuran kinerja selanjutnya bisa dijabarkan lebih luas pada capaian institusi secara lebih luas pada keterkaitan rencana strategis serta rencana induk pengembangan.

\section{DAFTAR PUSTAKA}

Akhtan, A. \&. G. R., 2013. Pengaruh Penempatan Kerja terhadap Kinerja Pegawai pada Dinas Perkebunan Provinsi Kaltim. E-Journal Administrative Reform, I(1), pp. 257271.

Antariksa, E., 2009. http://www.explorehr.org. [Online]

Available at: http://www.explorehr.org [Accessed 1129 2018].

Bayangkara, I., 2008. Audit Manajemen: Prosedur dan Implementasi. Jakarta: Salemba Empat.

David, F. R., 2011. A comprehensive strategic management model. In: E. Svendsen, ed. Strategic Management - Concept and Cases. New Jersey: Prentice Hall, p. 15.

Ginting, J., 2012. Pembelajaran Manajemen Audit Berbasis Kertas Kerja Pemeriksaan untuk Meningkatkan Hasil Belajar Mahasiswa Jurusan Akuntansi Fakultas Ekonomi UNIMED. Journal of Economics, 4(I), pp. 96-98.

Hamilton, A., 2008. Management Audit:Maximizing Your Company Efficiency and Effectiveness. s.1.:s.n.

Hasibuan, M., 2014. Manajemen Sumber Daya Manusia. Jakarta: Bumi Aksara.

Maharani, P. L. G. D. \&. S. R. M., 2014. Persepsi Karyawan atas Audit Manajemen Sumber Daya Manusia Pada Kinerja Karyawan. E-Jurnal Akuntansi Universitas Udayana, pp. 538-553.

Pembagio, N. S. N. U. \&. E. N., 2013. Pengaruh Proses Rekrutmen, Seleksi dan Kompetensi Karyawan terhadap Kinerja Karyawan. I(4), pp. 1-7.

Sartin, 2008. Analisis Perencanaan Tenaga Kerja di Perusahaan Redrying Tembakau. Jurnal Ekonomi dan Bisnis, I(3), pp. 224-232.

Siagian, S., 2015. Manajemen Sumber Daya Manusia. Jakarta: Bumi Aksara. 
Sugiyono, 2015. Metode Penelitian Kuantitatif, Kualitatif dan R\&D. Bandung: Alfabeta.

Sukrisno, A., 2013. Auditing. Jakarta: Salemba Empat.

Walker, G. M. J. R., 2001. Designing and Implementing an HR Scorecard. Human Resource Management, Volume 40, pp. 365-377.

Yullyanti, E., 2009. Analisis Proses Rekrutmen dan Seleksi pada Kinerja Pegawai. Jurnal Bisnis, III(16), pp. 131-139. 